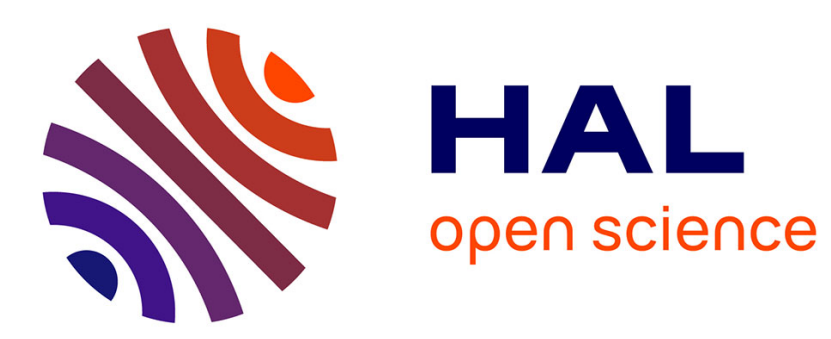

\title{
The Payment System and Liquidity Provision during the US National Banking Era
}

\author{
Laurent Le Maux
}

\section{To cite this version:}

Laurent Le Maux. The Payment System and Liquidity Provision during the US National Banking Era. Comparative Economic Studies, 2013, 55 (1), pp.459-473. 10.1057/ces.2013.12 . hal-01399603

\section{HAL Id: hal-01399603 https://hal.science/hal-01399603}

Submitted on 19 Nov 2016

HAL is a multi-disciplinary open access archive for the deposit and dissemination of scientific research documents, whether they are published or not. The documents may come from teaching and research institutions in France or abroad, or from public or private research centers.
L'archive ouverte pluridisciplinaire HAL, est destinée au dépôt et à la diffusion de documents scientifiques de niveau recherche, publiés ou non, émanant des établissements d'enseignement et de recherche français ou étrangers, des laboratoires publics ou privés. 


\title{
The Payment System and Liquidity Provision during the US National Banking Era
}

\author{
Laurent LE MAUX*
}

In Europe and the United States, governments progressively implemented the classical specie regime after periods of Revolutionary, Napoleonic or Civil wars, during which the inconvertible paper money regime had prevailed. Gold or silver specie were coined at the mint and several kinds of currency circulated at once, but all of the monies were not of equal status. All of them circulated among the public from hand-to-hand, while some of them were used as reserves by banking institutions. During the US National Banking Era (1863-1913), the circulations of different monies became particularly entangled. Thus, an analytical dichotomy between currency and liquidity is worth suggesting here. Currency refers to hand-tohand means of payment irrespective of their institutional characteristics (private bank notes, token money coined by local or national authorities, clearinghouse certificates, central bank notes, specie or paper money). Liquidity refers to interbank means of payment irrespective of its form (large-denominated central bank notes, clearinghouse loan certificates, balances at the clearinghouse or the central bank, specie or paper money) with which banking institutions settle interbank obligations. In this respect, specie or paper money is both currency and liquidity. Besides, the feature of central banking at first is the ability of discretionary provision of liquidity (as high-powered medium) within the banking system, while the issuance of the currency (as hand-to-hand medium) appears secondary.

\footnotetext{
* Associate Professor in Economics, University of Paris Saint-Denis, France. One version of this paper has been published in the Revue d'Economie Financière (2012) and the present version has been presented at the Storep Conference, Italy (2013) and will be published in the Comparative Economic Studies (2013).
} 
In Europe, the Banks of Issue progressively became central banks by playing the role of bankers' banks and not only that of banks that serve governments. The architecture of central banking under the specie regime relies, from a theoretical viewpoint, on the union of three functions that reinforce each other. The first is the centralisation of the metallic reserve and the issue of high-powered medium in the form of notes or banks' deposits. The second function is the stabilisation of the interest rate. The third function is the lender of last resort, defined as a prompt and massive issue of high-powered medium. In the case of Britain, during the classical period, the three functions were integrated within one institution and were fully fulfilled by the Bank of England - notably before the application of the Bank Act of 1844 (Le Maux, 2012). In the case of the United States, before the Federal Reserve Act of 1913, the banking system was, as commonly admitted, without an official central bank. In fact, the three central bank functions were observed but fulfilled by different institutions. First, the Treasury, the Clearing Houses and central reserve city banks centralised the metallic reserves. Second, the Treasury and the Clearing Houses attempted to smooth the interest rate according to the seasons or during banking panics. Third, the Treasury (during the crisis of 1873) and the Clearing Houses (from the crisis of 1873 to that of 1907) played the role of the lender of last resort by issuing high-powered medium. The New York Clearing House $(\mathrm{NYCH})$ consistently performed the three functions but was not a federal institution.

During the National Banking Era, the absence of the unification of the central bank functions within one federal institution was the result of a broader fragmentation, which is twofold in nature. The first division was regional. In the East and North, the industry was flourishing and developed banks played an active role in the money and financial markets. In the West and South, the economy was based on agriculture, and banks in the interior maintained correspondence with eastern and northern reserve city banks. The second fragmentation was institutional. The interior banks did not attempt to integrate the clearinghouse systems from the East and North, especially the NYCH system. Moreover, eastern banking institutions such as New York trust companies eschewed the clearinghouse supervision and the state regulatory framework. The present essay deals with this twofold fragmentation during the National Banking Era and its consequences on the payment system and the provision of liquidity. The first section briefly describes the monetary regime in place and the rule of issue built by the national banking laws. The second section examines the problem of the upward and downward inelasticity of the currency. Then, the third section apprehends the nature of the banking panics (especially those of 1873, 1893 and 1907) and distinguishes the hand-to-hand currency shortage from the interbank liquidity crisis. The fourth section clarifies the actions of the Clearing Houses (especially the $\mathrm{NYCH}$ ), which enhanced the supply of currency through the issue of certificates 
and more crucially provided liquidity to the interbank system through the issue of loan certificates. All of these categories could be intertwined and hence the fifth section concludes on the expected functions of the Federal Reserve System (FRS) in the early twentieth century.

\section{THE MONETARY REGIME AND THE NATIONAL BANKING SYSTEM}

From the definition of the unit of account by the Mint Act of 1792 to the creation of an official central bank system by the Federal Reserve Act of 1913, the monetary and banking history of the United States reveals the difficulty for a nation to establish a unified and integrated system of payment. With regard to the monetary regime, the Congress defined the unit of account and adopted the bimetallism regime in 1792 (Sylla, 2006). Specie was legal tender and all bank notes were legally convertible at the issuing bank's office at face value into silver or gold specie. Shortly after the outbreak of the Civil War, convertibility into specie was suspended in December 1861. The Congress adopted the Legal Tender Act in February 1862, which legalised the government's ability to issue inconvertible paper money (the greenback) and the legal amount reached US\$400 millions in March 1863. After the hostilities, the federal government planned to return to convertibility at the old parity: it started a policy of contraction of the quantity of greenbacks and froze it at $\$ 356$ millions in 1868 . The Coinage Act of 1873 cancelled the free minting of silver and the Resumption Act of 1875 hastened the return to convertibility into gold specie only. The Treasury reintroduced the policy of contraction until the premium on gold in terms of greenback vanished in May 1878. The amount of greenbacks was definitely frozen at $\$ 346$ millions and from 1 January 1879, the greenbacks were convertible into gold specie (Mitchell, 1903; Timberlake, 1993).

With regard to the banking architecture, the Congress adopted the National Currency Act in 1863 - renamed the National Bank Act in 1864 - which inaugurated the National Banking System (NBS) that prevailed until 1913. The NBS was the first attempt to unify the system of bank issuing to the extent that the national notes issued by the banks under federal charter (the national banks) should henceforth be exchanged at a one-to-one ratio from coast to coast. The Office of the Comptroller of the Currency of the Treasury was created in order to ensure the application of the regulatory components of the NBS. Three of them are worth recalling, as they appear important for our purposes. First, the rule for the issue of 
the national notes corresponded to a bond collateral requirement. The national banks were authorised to issue up to $90 \%$ of the amount of Treasury bonds after having purchased and deposited them with the Office of the Comptroller of the Currency. Analytically, it may be noted that the NBS rule dissociated the issue of bank notes from the discount or the acquisition of bills and linked their circulation to the bond collateral requirement - a circulation of backed notes, as I shall call them. Such a rule of issue turned its back on the traditional technique of discount by the issuing banks. In effect, the long-established practice associated the issue of bank notes with a discount or a purchase of private or public sector bills or securities - an issue of asset notes, as I shall call them. Second, the NBS defined the reserve requirement in lawful money (mainly, specie and greenbacks) against net deposits. Central reserve city banks of New York, Chicago and Saint Louis were required to maintain $25 \%$ of reserves (that should all be kept in vaults), reserve city banks throughout the nation were required to carry $25 \%$ of reserves (up to one-half of them could be held in central reserve city banks) and the country banks were required to carry $15 \%$ of reserves (up to three-fifths of them could be held in central reserve and reserve city banks). Goodhart (1969, p. 17) summarises the situation nicely: 'the entire banking system, partly by design, partly by accident, was intertwined by a spreading network of interbank balances' and 'the chain of interbank balances ended in New York'. Third, the national notes were legally convertible at face value into greenbacks until 1879 , and also into specie after 1879, and were mutually exchanged at par at the issuing bank's office. In order to improve par redemption of national notes outside the issuing bank's office, the Comptroller of the Currency put the National Bank Redemption Agency (NBRA) into operation in 1874 , which was a bureau of redemption and not a genuine, federally organised clearing system.

As we shall see in the next section, the absence of technique of asset notes issuing created an upward rigidity of the supply of the currency. On the other hand, the absence of a federal clearing institution that would have improved the reflux of national notes involved a downward rigidity of the currency. In other words, the procedure of national notes issue did not help national banks to respond promptly to the aggregate demand for currency - a problem known as the 'inelasticity' of the currency. 


\section{THE UPWARD AND DOWNWARD INELASTICITY OF THE NATIONAL NOTES ISSUANCE}

In autumn, harvests and trading of the agricultural production triggered a rise in transactions - and to a lesser extent, in late winter and early spring, planting also did so. In the country, within the agrarian community, the payment of wages, inputs and other transactions were mainly carried out with hand-to-hand means of payment, and a need for currency appeared from September to November. The bond collateral requirement impeded country banks from the interior from reacting immediately to the seasonal demand for currency by issuing asset notes. The national banks from the East, which corresponded with the interior banks, could not promptly issue asset notes either, and, finally, they were obliged to draw currency from their own reserve in specie or greenbacks. ${ }^{1}$

Different reasons explain such an upward inelasticity of the circulation of bank notes. First, in the short term, the demand for authorisation from a national bank, the purchase of eligible public bonds and their deposit with the Office of the Comptroller of the Currency, the transportation of national notes from Washington to rural areas, all of these operations were time-consuming. Second, the Treasury bonds deposited by the national banks as collateral against note issuance had long maturity - while most loans in the national bank portfolios ran for some months and could not easily be traded to face demand obligations. Third, in the long term, national banks permanently assessed the opportunity to issue notes by comparing the return on public bonds and the return on loans. If the later was higher than the former, they decided to make loans through an incremental rise in deposits to the detriment of notes circulation. Thus, when the interest rate on public bonds diminished with the government debt in the early 1880s, the circulation of the national notes fell from $\$ 360$ millions in 1882 to $\$ 172$ millions in 1892 . Following James (1976) explanation of under-issuance caused by the opportunity cost, Calomiris and Mason (2008) find, by disaggregating data, that the propensity to issue notes decreased when bond yields were lower, holding constant lending

\footnotetext{
${ }^{1}$ The Chamber of Commerce of New York (1907, p. 16) reported that: 'These harvests and the marketing of the crops bring to bear upon the banks a two-fold strain, one for capital, the other for currency. The demand for capital comes from the buyers and shippers of agriculture products and is in the main satisfied by an expansion of bank loans and deposits, most of the payments being made by checks and drafts. The demand for currency comes principally from the farmers and planters, who must pay their help in cash. In the satisfaction of this demand the banks are unable to make use of their credit, but are obliged to take lawful money from their reserves and send it into the harvest fields. As a result, the money reserves of banks are reduced at the very time when the demand for loans is increasing, and in consequence the rate of interest is advanced', see also Kemmerer (1910).
} 
opportunities measured by asset returns. ${ }^{2}$ From an analytical viewpoint, the backed note system of issuing for the most part explains the upward inelasticity. In contrast, the traditional technique of asset note issuing and (re)discount achieved by individual banks (a central bank) responds smoothly to the need of hand-to-hand means of payment. On the liability side, banks issuing asset notes simply change the form of their demand liabilities (diminution of demand deposits and augmentation in the amount of bank notes) without reducing their reserve holdings. On the asset side, they are able to grant any loan or acquire any bill through the issuance of bank notes or deposits, so that their lending opportunities remain equivalent regardless of the form of demand liabilities they choose to issue. It may be noted here that the Federal Reserve Banks were precisely able to provide such asset notes within the payment system.

After harvests in autumn and sowing in early spring, the decline of farming transactions from late spring to late summer involved a reduction of the interior demand for currency. Interior banks picked up and shipped a certain stock of currency and attempted to augment their reserve with their eastern correspondent. Eastern banks in turn collected national notes from all parts of the country and were not able to return them at once for repayment. They could keep part of them so as to put them back to the circulation before harvest, but they therefore bore opportunity costs. A paradox then took place: an unwanted currency stayed in their reserve during spring and summer, waiting to be 'reissued' in autumn. Eastern banks could also send interior notes to their Clearing Houses, which in turn assessed the opportunity to send them with a cost for repayment to each country banks' counter, or to the NBRA in Washington, from 1874 onwards. In short, national notes flowed back towards eastern cities, where they tended to be overabundant and stagnated until the harvest time.

Such a downward inelasticity of the supply of national notes may be explained by institutional features and to some extent by unit banking regulation. The problem did not result from the par redemption and the uniformity of the collateral.

\footnotetext{
${ }^{2}$ The literature on the NBS largely deals with the question of the profitability and the underissuance of national notes in the $1880 \mathrm{~s}$ and $1890 \mathrm{~s}$ - a 'puzzle' posed by Friedman and Schwartz (1963, p. 23). Bell (1912), Cagan (1965), Goodhart (1965), Duggar and Rost (1969), Cagan and Schwartz (1991), Champ, Wallace and Weber (1992), Champ, Freeman and Weber (1999) and Wallace and Zhu (2007) endorse the theory of redemption costs. Hetherington's (1990) explanation rests on the changes in the regulatory environment. James (1976) and Calomiris and Mason (2008) uphold the theory of opportunity costs. In showing that the time and regional variation in supply of national notes depended on time and regional variation profitability in bank lending, James (1976, pp. 363-364) comes to this conclusion: 'One of the ironies of this geographical difference in note issue is that the demand for currency against demand deposits is generally thought to have been higher in the West and South. However, it was in those rural western and southern states, where local loan rates were high, that bank notes were hardly issued'.
} 
The national notes were clearly distinct from one another and the Clearing Houses were therefore able to sort national bank notes they received and to implement active interbank note redemption at their regional level. In fact, the downward inelasticity mainly concerned national bank notes, which circulated from the interior and the East Coast. The par exchange system was not complemented by a federally organised clearing system and, as a result, the procedure of exchange and repayment of national notes was too cumbersome, costly and tardy. A federal or inter-regional clearing system would have routinely sponged national notes that were afloat in spring and summer and thus resolved the problem of downward inelasticity. However, on the one hand, the government failed to design such an institutional framework. Although the Clearing Houses in New York, Chicago, Boston or Philadelphia undoubtedly worked well, the problem was that they were only regional institutions and could not fulfil interbank relations with western and southern regions. On the other hand, the interior banks were reluctant to cooperate in an interstate clearing system and refused to open accounts with the eastern and northern Clearing Houses. From a regulatory viewpoint, their refusal was comforted by the legal prohibition of branch banking across state lines. From a theoretical viewpoint, a multilateral system of clearings involved an acceleration of the reflux of bank notes, especially those issued by banks lying on the periphery. Thus, the slow reflux of bank notes due to the absence of multilateral arrangements at an interregional level allowed interior banks to benefit from a lax constraint of liquidity and partly explained why they were reluctant to cooperate.

A Report of a Committee on the National Bank Currency Act from the directors of the NYCH, published as early as 1863 and cited by Selgin and White (1994, pp. 216-217), doubted the sustainability of the NBS and the efficiency of the system of repayment at par, only at the issuing bank's office: 'Suppose eight or ten millions, belonging nominally in as many different states, be put afloat in New York, how can the city get rid of them? By what process procure a redemption of this uncurrent money? Whose business will it be to save a hundred dollars of this bank, and a thousand of that, and send them to Wisconsin and Dakota, only to be protested, returned to New York?' Anticipating assorting and transportation costs, the Clearing Houses were prone to accept national notes at par that were issued by banks of its organisation or district, but accepted those issued by non-members at a discount. Concerned by the spread of such a practice, the Congress voted in favour of an amendment of the National Currency Act in June 1864, prohibiting any discount of national notes. This measure duly strengthened the banking integration within the Union, but it was not a complete integration for all, inasmuch as the legislator did not foresee any federally interlinked system of clearance. Banks in New York, Boston and Philadelphia proposed such a project under the aegis of the NYCH (Selgin and White, 1994, pp. 220-222). However, the interior banks refused to cooperate and to share the costs of transportation, assorting and clearing. 
Later, the Indianapolis Monetary Commission (1900) proposed a system of branch banking in order to implement intrabank - instead of and for want of interbank clearings. A draft was sent to the Congress but met once again with the opposition of the interior banks and their political representatives (Moen and Tallman, 1999, pp. 5-6). Discussing the proposal for central banking in the United States, Sprague (1909, p. 414) assessed that branch banking was an 'essential preliminary'. In the meantime, the National Bank Act of 1874 created the NBRA under the aegis of the Comptroller of the Currency. Each national bank was to deposit a redemption fund of up to $5 \%$ of its circulation, which was used to reimburse the national notes that returned to the NBRA and to support operation costs. The NBRA was not a federal clearinghouse or a central bank dealing with interbank accounts, but a simple bureau of redemption. However, it contributed to improving the circulation and the reflux of the national notes. Most of them were returned by banks from New York, Boston and Philadelphia. Not surprisingly, the interior national banks complained about the acceleration of the reflux of their notes.

In summary, the interior national notes floated in spring from the interior to the East and in autumn in the opposite direction, without passing through the net of a federal clearing system - when city national notes more frequently passed through the net of the city Clearing Houses. The interior national notes were kept by eastern banks until the stream of commerce sent them back when demand was high during harvest time. Such was the pendulum built into the NBS. The status of national bank notes did not depend on the institutions (eg central bank notes used as structural reserve by commercial banks) but changed in time according to periods (eg national notes used as seasonal reserve by any banking institution). Furthermore, the instability of the status of the national notes that depended on the seasons partly explains the instability of banks' reserve and short-term interest rate (call loan rates) in financial centers.

\section{THE NATURE OF THE BANKING CRISES: CURRENCY SHORTAGE AND LIQUIDITY CRISES}

The distinction between currency and liquidity stated in the introduction helps analyse bank runs and changes in short-term interest rates during the national banking period. With regard to bank runs, (1) when inelasticity of the currency reaches an extreme level, banks suffer from a run to currency that concerns deposits; and (2) when the distrust threatens the banking system irrespective of (in)elasticity of the currency, banks suffer from a run to liquidity that concerns all 
their liabilities, bank notes, as well as deposits. With regard to interest rate changes, just as a distinction between the inelasticity of the currency and the crisis of liquidity, a distinction must be made between (1) the seasonality of the interest rate due to the inelasticity of the currency and (2) the instability of the interest rate owing to financial disturbances and pressure on the money market. It is worth noting that the traditional practice of the issue of asset notes mostly settles the problem of currency shortage by changing the form of demand liabilities without diminishing reserves and prevents seasonal changes in the interest rate; however, it by no means cancels liquidity crisis and interest rate instability during financial turmoil.

With regard to bank runs, the severe banking panics of 1873 and 1907 took place in autumn and both runs to currency and runs to liquidity occurred. The evolution of the New York City national banks' balance sheet between early September and late October 1873 illustrates the seasonal pressure on their currency reserve (Timberlake, 1993, p. 106). The circulation of bank notes on the liabilities side of the New York City national banks' balance sheet was stable, while the amount of deposits reserves in lawful money plummeted. In order to respond to the demand for currency, the New York City national banks had no choice but to withdraw greenbacks from their reserves. However, the seasonal withdrawal of currency cannot solely explain the crisis of 1873. Actually, after a period of speculation and credit boom in the railway industry, the stock market prices in New York fell by $25 \%$ in a week before the closure of the Stock Exchange for 10 days. As a consequence, the market liquidity vanished and the banking institutions became vulnerable to run to liquidity. Calomiris and Gorton (1991) study the banking panics throughout the National Banking Era and find that they were not preceded by the larger seasonal shocks, but rather accompanied by disturbances in the stock markets or the land markets. ${ }^{3}$ The shortage of the currency in autumn worsened, but was by no means the sole explanation of the crash of 1873 . It even had no effect during the crisis of 1893 , which took place in spring and summer, a period of overabundance of currency.

One solution from the monetary authorities was to issue greenbacks, which constituted currency and liquidity at the same time. The Treasury could not create them at his discretion and needed the vote of the Congress. Only in 1873 did the Congress consent to the creation of greenbacks for an amount of $\$ 26$ millions

\footnotetext{
${ }^{3}$ Calomiris and Gorton (1991) challenge the random withdrawal model of banking panics (Diamond and Dybvig, 1983) and attempt to illustrate the relevance of the asymmetric information model (Gorton, 1987; Calomiris and Kahn, 1991). Carlson (2005) grounds his interpretation of the crisis of 1893 on hybrid models (Morris and Shin, 2001; Goldstein and Pauzner, 2005), in which asymmetric information, as well as random withdrawal, are taken into account.
} 
(among the 'reserve' of $\$ 44$ millions). ${ }^{4}$ In 1893 , the panic started in April in the interior, where numerous banks failed (Wicker, 2000; Carlson, 2005). They did not have access to a lender-of-last-resort service from the Treasury or the NYCH. At that time, the Treasury was facing a monetary crisis. Its gold reserve fell under $\$ 100$ millions and it was not willing to issue greenbacks as it had done in 1873, or to transfer any metallic reserve to interior banks against securities. Moreover, as seen in the previous section, the interior banks had refused any cooperation with the $\mathrm{NYCH}$ in previous decades, and thus could not benefit from its liquidity provision. When the crisis spread to New York in summer, the NYCH began to issue loan certificates to its member banks and injected a total of $\$ 41$ millions of liquidity. The intervention of the Clearing Houses of New York, Boston and Philadelphia did not, however, counter the drains of liquidity from the East towards the interior. ${ }^{5}$ As interior banks were not members of the eastern Clearing Houses, no catalytic effect owing to lending of last resort could arise throughout the territory.

With regard to the market interest rate, the pendulum of the national notes circulation triggered, in turn, seasonal movements. In spring and summer, the overabundance of liquidity led the eastern banking institutions to easily grant shortterm credit (call loans). Afterwards, in autumn, the reduction of the eastern banks' reserves led to a decline of their credit capacity and a rise in call loan rates. In this respect, the NBS is often compared with the Canadian banking system at the same period. In Canada from 1890 onwards, as in the United States from 1864 onwards, issuing banks were compelled to reimburse their notes at par. The two main differences were: first, Canadian banks issued asset notes through the technique of discount of commercial bills; second, they could legally open branches from coast to coast and thus carried out intrabank - if not interbank - clearings. Thus, the supply of bank notes remained rigid all year long in the United States, whereas in Canada it was responsive to seasonal transactions. The US national banks' reserves

\footnotetext{
${ }^{4}$ The difference of $\$ 44$ millions between the maximum legal amount of $\$ 400$ millions and the freeze of the amount of greenbacks to $\$ 356$ millions in 1868 has been called the 'reserve' and was the maximum discretionary amount of greenbacks that the government was allowed to create. The Act of 1874 froze the amount of greenbacks to $\$ 382$ millions, which sanctioned the issue of $\$ 26$ millions by the Treasury during the 1873 crisis. After the policy of contraction of greenbacks was reinstated in 1875, the Congress finally froze the amount of greenbacks to \$346 millions in 1878 .

${ }^{5}$ On the interior drain in the summer of 1893 , see Noyes (1898, p. 193): 'During the month of July, in the face of their own distress, the New York banks were shipping every week as much as $\$ 11,000,000$ cash to [the interior] institutions. Ordinarily, such an enormous drain would have found compensation in import of foreign gold, and, in fact, sterling exchange declined far below the normal gold-import point'. On the interior drain in the autumn of 1907, see also Sprague (1908, p. 365): 'During two weeks ending November $2 \mathrm{nd}$, [the New York banks] sent $\$ 42,000,000$ to interior banks [...]. In the meantime, gold imports to the amount of $\$ 29,000,000$ had been engaged with more in respect'.
} 
were more prone to fluctuate than those of Canadian banks', and the call loan rate was volatile in New York and stable in Montreal. ${ }^{6}$ However, the explanation for the instability of the interest rate based only on seasonal demand for currency and its inelastic supply is no longer relevant in the case of financial turmoil. In effect, no seasonal shock could explain how the call loan rate in New York could rise as high as 186\% during London's banking crisis in 1890 (Noyes, 1898, p. 158) or 125\% during the crisis of 1907 (Goodhart, 1969, p. 133). Securities and shares markets in New York City were more developed than those in Montreal and any financial shock triggered more severe runs to liquidity. In such a context, the NYCH acted as the lender of last resort and set a 6\% interest rate (Myers, 1931). This provision of funding liquidity contributed to mitigating to some extent the instability of interest rate within the interbank market.

The crisis of 1907 combines all of the difficulties encountered by the US banking system before the creation of the FRS. It was not only worsened by the inelasticity of the currency in autumn (as in the crisis of 1873), by regional fragmentation (as in the crisis of 1893), but also by a regulatory distortion between national banks and shadow banks such as trust companies, especially in New York. Trust companies emerged as financial intermediaries in the late nineteenth century and the banking law of New York authorised them to receive deposits and to purchase and sell stocks, bills of exchange, bonds and mortgages. Noyes (1901, pp. 252-253) indicates that the main difference between the law for trust companies and the law for banks resulted from the conception of the trust company as a 'trustee', which 'is not required to keep on hand as a reserve any sum of idle cash'. The New York trust companies had clearly become depository institutions and they should have been precisely placed on the same footing as the deposit banks. The trustee framework was undoubtedly a case of regulatory arbitrage in banking, especially concerning the cash reserve requirement. ${ }^{7}$ Noyes (1901, p. 259) continues: 'it is, then, not surprising that the New York Clearing House has by resolution required the trust companies, which are allowed to clear checks through

\footnotetext{
${ }^{6}$ See Goodhart (1969, pp. 306-320), Selgin and White (1995, pp. 193-194), Champ et al. (1996, pp. 850-858) for data. It may be recalled at this stage that the FRS was precisely designed to smooth the seasonality of the interest rate. An interpretation related to the legal restriction theory claims that the seasonality of the interest rate was not due to the absence of the central bank, but instead to the legal constraints on note issuing. In this line of reasoning, Horwitz (1990) criticises Miron (1986) for not taking into account that the bond collateral requirements were a major cause of the seasonality of the interest rate. However, the instability of the interest rate due to financial disturbances was another matter.

${ }^{7}$ Indeed, the New York trust companies in 1901 held less than $1.5 \%$ of cash reserve against their deposits, whereas the national banks outside the larger cities in New York State and the New York City national banks held, respectively, $12.75 \%$ and $26 \%$ of cash reserve against their deposits (Noyes, 1901, p. 256). Moreover, assets of New York trust companies increased 2.5 times more than the assets of New York national banks during the decade preceding the 1907 crisis (Neal, 1971, p. 43).
} 
it, to submit frequent and detailed statements of their operations'. In effect, in 1903 and 1904, the $\mathrm{NYCH}$ required a larger reserve ratio from the trust companies in order to converge towards regulatory uniformity within its organisation and improve the stability of the banking system at large (Sprague, 1908, pp. 359-360; Smith, 1928, pp. 347-350). New York trust companies that were not members of the NYCH refused to comply with these new entry requirements, and some member trust companies decided to leave it in order to maintain their competitive advantage. As Noyes (1901, pp. 260-261) perfectly concludes, 6 years before the collapse: 'It is not at all necessary to assume that trouble will come through dishonest or reckless management. There is a broader question lying behind the whole problem of the trust companies. [...] The trust company, under its present status, is as much subject to a run of depositors. [...] The present status of the law constitutes an element of the greatest danger for the future'.

During the Panic of October 1907, the NYCH injected \$101 millions in loan certificates in aid of member banks (national banks and state banks, mainly) and significantly helped stabilise their liquidity and their credit supply, but it did not straightforwardly provide assistance to the New York trust companies, whose balance sheets fell in size (Moen and Tallman, 1992, 2000). ${ }^{8}$ Two interpretations (not mutually exclusive) may be suggested: either the $\mathrm{NYCH}$ actively attempted to manage risk-taking and moral hazard, or the lack of information on the New York trust companies restricted the NYCH in granting them direct loans. In any case, the $\mathrm{NYCH}$ first favoured lending to national banks, which had close ties with trust companies and could be in a position to grant them emergency loans. Even if New York City national banks could have been reluctant to lend to rival and unregulated institutions, they did transfer them a share of the funding liquidity. As Sprague (1908, p. 361) described, 'they had to furnish most of the money required by the trust companies, whose reserves were deposited with them, and at the same time they were shipping money to the interior for crop moving purposes'. The crisis of

\footnotetext{
${ }^{8}$ The studies provided by Moen and Tallman $(1992,2000)$ are not limited to New York City banking institutions and specify that the trust companies were not systematically outside a clearing system throughout the United States. Several Chicago trust companies were members of the Chicago Clearing House, whereas few Illinois state banks were not. Thus, the crisis of 1907 had different consequences in Chicago than in New York: the Chicago trust companies had access to lending in last resort from the Chicago Clearing House and were less affected than the Illinois state banks. Banking institutions that were members of the Clearing House system and under its supervision (in New York and in Chicago) could more easily enjoy the lender-of-last-resort service and were less vulnerable to the financial turmoil. Concerning the crisis of 1893, Hoag (2011) finds different results than those of Moen and Tallman. On the Panic of 1907, one might also refer to Bruner and Carr (2007); Frydman et al. (2012); Noyes (1909); Sprague (1910). Lastly, it may be noted that the Treasury deposited in October 1907 metallic reserve for an amount of $\$ 25$ millions in New York City banks (Sprague, 1908, p. 362; Timberlake, 1993, p. 195). This was no longer an issue of liquidity (greenback) but a transfer of liquidity (specie).
} 
1907 is instructive. The obstacle of the effective resolution of the crisis was not the absence of a lender of last resort, especially as the information production, supervision activity and lending in last-resort provision from the $\mathrm{NYCH}$ to its members were not questionable. The real problem was the extent of its sphere of intervention from a regional, as well as institutional, point of view. Notably, unregulated banking institutions bearing important risks in their portfolios stayed outside of the NYCH system. The reader might establish a comparison with the crisis of 2007-2009, during which shadow banks and investment banks, whose asset holdings have been proved highly risky, were outside the supervision, regulation and liquidity provision (at least prior to the crisis) of the FRS.

\section{THE ACTION OF THE CLEARING HOUSES: CURRENCY ISSUE AND LIQUIDITY PROVISION}

Among the US Clearing Houses (Cannon, 1910), the NYCH played an important role in the East coast during the National Banking Era. It performed most of the central bank functions in organising multilateral offsetting of bank notes and checks, centralising part of the money reserve, issuing in last resort high-powered medium in the form of loan certificates, and thus mitigating interest rate instability in times of liquidity pressure. Initially, the denominations of the clearinghouse issues were as large as $\$ 5,000$ or $\$ 10,000$ (loan certificates) and were used as means of settlement among banks and interbank liquidity. Then the denomination became smaller and smaller (certificates) and these were issued to counter the problem of the upward inelasticity of the currency. The distinction established in the previous section between run to currency and run to liquidity highlights the action of the Clearing Houses under the NBS. Hence, two kinds of issue of clearinghouse certificates are detailed below, namely: (1) small-denominated certificates as an instrument to respond to currency shortage and a consequence of the NBS rule of issue, and (2) large-denominated loan certificates as an instrument to counter run to liquidity and an institutional innovation mitigating financial and banking turmoil.

The provision of currency by the Clearing Houses took the form of certificates, which ranged in denomination from $\$ 1$ to $\$ 20$, and were used for the payment of wages and retail transactions. As depicted by Andrew (1908, p. 509), 'many of the certificates were elaborately engraved (y) and were shaped and colored so as to resemble ordinary bank or government notes'. The directors of the Clearing Houses denied that these issues could have any monetary features. As banking institutions 
issuing certificates or notes outside of the NBS rule, they should have been constrained to pay the tax of $10 \%$ like any issuing state banks. However, the payment service that the Clearing Houses rendered in autumn led the government not to sue them (Timberlake, 1993, p. 207). The debate on whether smalldenominated certificates were or were not currency should not hide the fundamental point, that is, the action of the Clearing Houses as lenders of last resort and liquidity providers during banking panics. The provision of liquidity took the form of issuance of the loan certificates, which ranged in denomination from $\$ 500$ to $\$ 20,000$, and were used for the settlements of interbank balances. Data provided by Andrew (1908, p. 515) shows that (large-denominated) loan certificates reached the amount of $\$ 238$ millions during the crisis of 1907 , while (small-denominated) certificates reached \$23 millions. Loan certificates responded to a need of funding liquidity in the interbank markets once banks suffered from an erosion of their asset holdings valuation and market liquidity, and not to a demand for hand-to-hand currency from the public. Moreover, the decline of the bank liquidity was also triggered by depositors worried about the solvency of their banks, irrespective of the problem of the upward inelasticity of the currency. Then, the Clearing Houses were led to issue loan certificates in smaller denominations and their circulation (countering run to liquidity from depositors) could intermingle with large certificates (responding to run to currency). In any case, the Clearing Houses allowed banks to free up lawful currency held in their reserves to face withdrawal from depositors and resolved the problem of coordination between banks with a surplus of liquidity and banks with deficits.

With regard to the NYCH, Wicker (2000) provides a detailed study of its action during banking panics. According to him, the NYCH successfully managed the crises of 1884 and 1890, and managed that of 1873 with qualified success, and failed to manage the crises of 1893 and 1907. Wicker (2000, pp. 111, 140) concludes that there was an 'institutional failure' from the $\mathrm{NYCH}$. It must be pointed out nonetheless that the interior banks (affected by the 1893 crisis) and also the New York trust companies (affected by the 1907 crisis) had previously refused to participate in the clearing system and to submit to prudential control. More than the supposed institutional failure, the refusal of cooperation from interior banks and from New York trust companies, respectively, explains the delay of the $\mathrm{NYCH}$ intervention during the crisis of 1893 and the reluctance to intervene in aid of shadow institutions during the crisis of 1907. Moreover, the NYCH did not enjoy the help of the federal legislator and the state legislator, respectively, in constraining the interior banks in the late nineteenth century and the New York trust companies in the early twentieth century to hold an account within its organisation and respect its prudential rules. In other words, NYCH supervisory power was regionally and institutionally limited, meaning that the institutional failure came instead from the state or federal regulator. 
It may be noted that the Treasury had or could have had an important role as a provider of liquidity, but its action was restricted. On the one hand, the Treasury could issue high-powered money in the form of greenbacks. However, the policy of return to convertibility was such that the circulation of greenbacks decreased by more than $20 \%$ between 1865 and 1878 and remained frozen to $\$ 346$ millions afterwards, which rendered any action as a lender of last resort difficult. Even if the Secretary of the Treasury agreed to intervene, any injection of greenbacks necessitated the vote of the Congress - as had been the case in 1873 - and their circulation could not increase beyond the legal ceiling of $\$ 400$ millions. On the other hand, the Treasury held a large part of the metallic reserve of the nation and maintained a reserve ratio of around $30 \%$ of the greenbacks in circulation. The Secretary of the Treasury attempted in this way to overcome the inconvenience of the NBS and to lessen the seasonality of the interest rate by transferring metallic reserves in autumn and withdrawing them in spring. During the banking panics, the Treasury could deposit significant amounts of metallic reserve in national banks as had been the case in 1907. However, these measures did not strictly correspond to lending of last resort defined as an issue of high-powered medium. Anyhow, the Treasury's room for manoeuvre was quantitatively and institutionally limited.

\section{CONCLUSION}

The analytical distinction between hand-to-hand currency shortage and funding liquidity crisis infers categories such as runs to currency and to liquidity, seasonality and instability of the interest rate, and issuance of small-denominated notes and high-powered medium. In order to resolve the problem of run to currency, the Congress passed the Aldrich-Vreeland Act in 1908 that authorised some national banks to issue 'emergency currency' outside the NBS rule (Laughlin, 1908) and set up the National Monetary Commission, which took place in 1910. The ensuing Aldrich project intended to create the 'third' bank of the United States - the National Reserve Association. A large participation of banking institutions to the central bank and its supervision system was promoted, including national banks, state banks and even trust companies.

The Aldrich project did not come off in consequence of the Democrats' victory in the 1910 Congressional elections and 1912 Presidential elections. It was supplanted by the less ambitious Glass project - the FRS. The large participation was no longer on the agenda and only the national banks had to become member banks. The Federal Reserve Banks could issue asset notes and were federally 
linked. Their purpose was 'to furnish an elastic currency, to afford means of rediscounting commercial paper' notably in order to smooth interest rate changes. However, it could have led to a quid pro quo on the meaning of 'elasticity' of the Federal Reserve Banks' issues. It could mean the supply of hand-to-hand currency at the discount window against private assets, or the provision of funding liquidity at the discount window or the open market procedure. In other words, it was not quite clear whether the FRS was mainly created to allow Federal Reserve Banks to issue asset notes instead of the backed notes that prevailed during the NBS, or to formalise the existence of a federal lender of last resort. In sum, the question remained as to whether the FRS was thought of as an institution rendering a simple payment service, or as an institution ensuring the stability of the banking and financial system as a whole. ${ }^{9}$ In addition, the purpose of the Federal Reserve Banks was also 'to establish a more effective supervision of banking in the United States'. However, many banking institutions remained outside the supervision of the central bank inasmuch as participation in the FRS was not legally compulsory except for the national banks. The present essay has pointed out that partial participation had been dramatic during the banking panics of 1893 and 1907 and it might be shown that this was also the case during the financial collapses of 19301933 and 2007-2009.

\footnotetext{
${ }^{9}$ The quid pro quo was pointed out early on by Sprague (1909). On the one hand, it is said that: 'An elastic currency is the panacea which has been most generally prescribed for our financial ills, and it is largely because a central bank is believed to be an effective means to this end that its adoption has been urged. This is not, indeed, always a function of central banks' (ibid., p. 384). On the other hand, it is recognised that: 'In times of acute financial panic the central bank plays an active dominating rôle. Upon it rests the responsibility for maintaining specie payments, and also in large measure for the continuance of lending facilities to the business community' (ibid., p. 400). Then, Sprague (1909, p. 411) rightly concludes that: 'We need an elastic reserve policy far more than an elastic currency'.
} 


\section{REFERENCES}

Andrew A. P. 1908: Substitutes for cash in the Panic of 1907. Quarterly Journal of Economics 22(4): 497-516.

Bell S. 1912: Profit on national bank notes. American Economic Review 2(1): 3860 .

Bruner R. F. and Carr S. 2007: The Panic of 1907: Lessons learned from the market's perfect storm. John Wiley: Hoboken, NJ.

Cagan P. 1965: Determinants and effects of changes in the stock of money, 18751970. Columbia University Press: New York.

Cagan P. and Schwartz A. J. 1991: The national bank note puzzle reinterpreted. Journal of Money, Credit and Banking 23(3): 327-355.

Calomiris C. W. and Gorton G. 1991: The origins of banking panics: Models, facts, and bank regulation. In: Hubbard RG (ed). Financial Markets and Financial Crisis. University of Chicago Press: Chicago, pp. 109-173.

Calomiris C. W. and Kahn C. M. 1991: The role of demandable debt in structuring optimal banking arrangements. American Economic Review 81(3): 497-513.

Calomiris C. W. and Mason J. R. 2008: Resolving the puzzle of the underissuance of national bank notes. Explorations in Economic History 45(3): 294-307.

Cannon J. G. 1910: Clearing houses: Their history, methods, and administration. National Monetary Commission, 61st Congress, 2nd Session, Government Printing Office: Washington DC.

Carlson M. 2005: Causes of bank suspensions in the Panic of 1893. Explorations in Economic History 42(1): 56-80.

Chamber of Commerce of New York. 1907: Forty-ninth annual report of the corporation of the Chamber of Commerce of the State of New York, for the Year 1906-1907. Press of the Chamber of Commerce: New York.

Champ B. Freeman S. and Weber W. E. 1999: Redemption costs and interest rates under the US national banking system. Journal of Money, Credit and Banking 31(3): 568-589.

Champ B., Smith B. D. and Williamson S. D. 1996: Currency elasticity and banking panics: Theory and evidence. Canadian Journal of Economics 29(4): 828-864.

Champ B., Wallace N. and Weber W. E. 1992: Resolving the national bank note paradox. Federal Reserve of Minneapolis Quarterly Review 16(2): 13-21. 
Diamond D. W. and Dybvig P. H. 1983: Bank runs, deposit insurance, and liquidity. Journal of Political Economy 91(3): 401-419.

Duggar J. W. and Rost R. F. 1969: National bank note redemption and treasury cash. Journal of Economic History 29(3): 512-521.

Friedman M. and Schwartz A. J. 1963: A monetary history of the United States, 1867-1960. Princeton University Press: Princeton.

Frydman C., Hilt E. and Zhou L. Y. 2012: Economic effects of runs on early 'Shadow Banks': Trust companies and the impact of the Panic of 1907. NBER Working Papers Series No. 18264.

Goldstein I. and Pauzner A. 2005: Demand-deposit contracts and the probability of bank runs. Journal of Finance LX(3): 1293-1327.

Goodhart C. A. E. 1965: Profit on national bank notes, 1900-1913. Journal of Political Economy 73(5): 516-522.

Goodhart C. A. E. 1969: The New York money market and the finance of trade, 1900-1913. Harvard University Press: Cambridge.

Gorton G. 1987: Bank suspension of convertibility. Journal of Monetary Economics 15(2): 177-193.

Hetherington B. W. 1990: Bank entry and the low issue of national bank notes: A reexamination. Journal of Economic History 50(3): 669-675.

Hoag C. 2011: Clearinghouse membership and deposit contraction during the Panic of 1893. Cliometrica 5(2): 187-203.

Horwitz S. 1990: Competitive currencies, legal restrictions, and the origins of the fed: Some evidence from the Panic of 1907. Southern Economic Journal 56(3): 639-649.

Indianapolis Monetary Commission. 1900: Report of the Monetary Commission of the Indianapolis Convention. Hollenbeck Press: Indianapolis.

James J. A. 1976: The conundrum of the low issue of national bank notes. Journal of Political Economy 84(2): 359-368.

Kemmerer E. W. 1910: Seasonal variations in the relative demand for money and capital in the United States: A statistical study. National Monetary Commission, 61st Congress, 2nd Session, Government Printing Office: Washington DC.

Laughlin J. L. 1908: The Aldrich-Vreeland act. Journal of Political Economy 16(8): 489-513. 
Le Maux L. 2012: Banque centrale et finance: la Banque d'Angleterre, le taux d'intérêt et le Bank Act de 1844. Research Report, EHESS, Paris.

Miron J. A. 1986: Financial panics, the seasonality of the nominal interest rate, and the founding of the fed. American Economic Review 76(1): 125-140.

Mitchell W. C. 1903: A history of greenbacks. University of Chicago Press: Chicago.

Moen J. R and Tallman E. W. 1992: The Panic of 1907: The role of trust companies. Journal of Economic History 52(3): 611-630.

Moen J. R. and Tallman E. W. 1999: Why didn't the United States establish a central bank until after the Panic of 1907. Working Paper Series 99-16, Federal Reserve Bank of Atlanta, Atlanta, November.

Moen J. R and Tallman E. W. 2000: Clearinghouse membership and deposit contraction and during the Panic of 1907. Journal of Economic History 60(1): 145-163.

Morris S. and Shin H. S. 2001: Rethinking multiple equilibria in macroeconomic modeling. NBER Macroeconomic Annual 2000 15: 139-161.

Neal L. 1971: Trust companies and financial innovations, 1897-1914. Business History Review 45(1): 35-51.

Myers M. G. 1931: The New York money market, Vol. 1, Columbia University Press: New York.

Noyes A. D. 1898: Thirty years of American finance. G.P. Putnam: New York..

Noyes A. D. 1901: The trust companies: Is there danger in the system. Political Science Quarterly 16(2): 248-261.

Noyes A. D. 1909: A year after the Panic of 1907. Quarterly Journal of Economics 23(2): 185-212.

Selgin G. A and White L. H. 1994: Monetary reform and the redemption of national bank notes, 1863-1913. Business History Review 68(2): 205-243.

Selgin G. A. and White L. H. 1995: National bank notes as a quasi-high powered money. In: Thies CF (ed). Money and Banking: The American Experience. George Mason University Press: Fairfax, Virginia, pp. 169-199.

Smith J. G. 1928: The development of trust companies in the United States. H. Holt: New York.

Sprague O. M. W. 1908: The American crisis of 1907. Economic Journal 18(71): 353-372. 
Sprague O. M. W. 1909: The proposal for a central bank in the United States: A critical view. Quarterly Journal of Economics 23(3): 363-415.

Sprague O. M. W. 1910: History of crises under the national banking system National Monetary Commission, 61st Congress, 2nd Session, Government Printing Office, Washington DC.

Sylla R. 2006: The transition to a monetary union in the United States, 1787-1795. Financial History Review 13(1): 73-95.

Timberlake R. H. 1993: Monetary policy in the United States: An intellectual and institutional history. University of Chicago Press: Chicago.

Wallace N. and Zhu T. 2007: A float on a note. Journal of Monetary Economics 54(2): 229-246.

Wicker E. 2000: Banking panics in the gilded age. Cambridge University Press: Cambridge, MA.

\section{SUMMARY}

This essay distinguishes hand-to-hand currency shortage from the funding liquidity crisis in order to apprehend the nature of disruptions of the payment system during the US National Banking Era (1863-1913). Different analytical categories are thus inferred, namely, runs to currency and to liquidity, seasonality and instability of the interest rate, and issuance of small-denominated certificates and large-denominated loan certificates by the Clearing Houses. All of these categories were particularly intertwined under the National Banking System, which may have led to a quid pro quo related to the expected functions of the Federal Reserve System. 